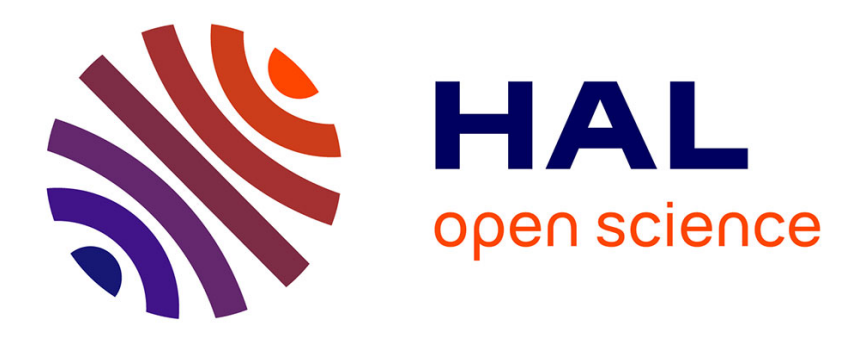

\title{
Using Focus Groups to Study the Process of (de)Politicization
}

\author{
Sophie Duchesne
}

\section{To cite this version:}

Sophie Duchesne. Using Focus Groups to Study the Process of (de)Politicization. Rosaline S. Barbour; David L.Morgan (eds). A New Era of Focus Group Research, Palgrave macmillan, pp.365-388, 2017, 978-1-137-58613-1. halshs-01674453

\section{HAL Id: halshs-01674453 \\ https://shs.hal.science/halshs-01674453}

Submitted on 2 Jan 2018

HAL is a multi-disciplinary open access archive for the deposit and dissemination of scientific research documents, whether they are published or not. The documents may come from teaching and research institutions in France or abroad, or from public or private research centers.
L'archive ouverte pluridisciplinaire HAL, est destinée au dépôt et à la diffusion de documents scientifiques de niveau recherche, publiés ou non, émanant des établissements d'enseignement et de recherche français ou étrangers, des laboratoires publics ou privés. 


\section{Chapter 17 - Using Focus Groups to Study the Process of (de)Politicization}

Sophie Duchesne (CNRS/Sciences Po Bordeaux), France.

s.duchesne@sciencespobordeaux.fr

Pre-print version, final. August 2016

Published in Rosaline Barbour and David Morgan eds., A New Era of Focus Group Research, Palgrave macmillan, 2017 (p.365-387).

The growing distance that seems to characterize the relationship that citizens entertain with politics - in Western democracies, in particular - is matter for concern. How to make democracy work when those who are supposed to be the source of legitimate power don't bother to engage? (Hay, 2009; Stoker, 2009) Although the causes of citizens' de-politicization are most probably largely external to them - as, for instance, the disappearance of social capital, the role of modern media, globalization and the blurring of political accountability, neoliberalism and the individualization of social relations (Zürn, 2016) - their effects should also be analyzed, observed and interpreted. Interrogating such effects is all the more important, if we hope to find triggers that would help in reversing the trend of depoliticization.

Focus groups might prove useful for studying (de)politicization - provided that they are designed appropriately. I did have experience of this in a study dedicated to attitudes towards European integration (Duchesne et al., 2013) ${ }^{\mathrm{i}}$. The original project aimed to analyze a more specific process, conflictualization, i.e. how people accept or avoid conflict in public discussion. We first conducted an experimental series of three groups on delinquency which yielded promising insights (Duchesne and Haegel, 2010, 2004). We decided to replicate the study in a broader setting, in order to compare the French dynamic we had already observed 
with other national contexts. We looked for funding and, for different reasons, ended up with a project where European integration became the topic to be discussed. We ran the series of groups, about thirty collective interviews in three cities, and contrary to our previous study, hardly got conflictive discussions, even in the French groups. We first tended to consider that our design had gone wrong - mostly because of the topic ${ }^{\mathrm{ii}}$ : the European Union was clearly not something to which people could relate directly ${ }^{\mathrm{iii}}$ and participants recurrently indicated that they consider it a political issue; the kind of issue they would never discuss spontaneously. They thus found it difficult to adjust to a situation that was obviously quite strange to them. We looked closer into this and concluded that the situation we had created in these focus groups was indeed a "test of politicization": that is, a situation where participants were directly and inadvertently confronted with politics ${ }^{\text {iv }}$. My objective in this chapter is to follow up on this serendipitous finding and to underline crucial issues one should address in designing focus groups as test of politicization. One justification for this is also that a large part of the methodological literature regarding focus groups is written by scholars specialized in health sciences (Barbour, 2007). Mainstream sociology and political science are still a bit late in this regard, although the method has, more recently, become quite fashionable in these disciplines (See for example Dervin, 2015; Garcia and Haegel, 2011; Guillemette, Luckerhoff, and Baribeau 2010a, 2010b).

In the first section of this chapter, I will return briefly to what politicization means and underline the reasons why focus groups need to be designed in specific ways in order to address this topic. In the second section, I will put forward three points that seem to me particularly important here: recruiting purely lay citizens; combining homogeneity and heterogeneity in the sampling; and moderating in a non-directive way. In the last section, I will discuss how to analyze this data. 
1. Politicization and focus groups: elective affinities.

In political theoretical terms, politicization means that we should address issues as objects of collectively binding decision-making (de Wilde, Leupold, and Schmidtke, 2016) - that is, through considering problems as collectively shared and as a matter of agency (White, 2010). Yet, from a sociohistorical and sociological point of view, politics is a specific and, even, specialized field, whose (relative) autonomy can be traced back historically in societies. Politicization, thus, can be understood as a process involving infringement of the borders of this specific field (Lagroye, 2003). This happens, on the one hand, when any kind of issue becomes a matter of political debate; on the other hand, when lay citizens become involved in political affairs. At the individual level, this infringement requires some degree of political sophistication, in combination with some conscience of it ${ }^{\mathrm{v}}$. Alternatively, politicization proceeds from citizens' ability to adapt to the political order by “translating” into political categories, ways of thinking and arguing learned and experienced in other social circumstances (Déloye, 2007).

In particular, when lay citizens "talk politics”vi , they rephrase or reinterpret political categories into categories with which they are familiar: that is, they rely on experiences and meanings taken from their ordinary lives to make sense of political questions, issues or events under discussion. This process is, thus, to be studied as a heuristic object, allowing for the empirical analysis of the cognitive (and yet socially and politically determined) discrepancies between the political field and other fields familiar to lay citizens.

The borders and possible translations between the political field and other ones vary in time and space. However, as an infringement that requires knowledge and/or abilities, politicization is necessarily limited and representative democracy is actually based on this limitation $^{\text {vii }}$. Mass citizenship, based on universal suffrage, maintains the idea of universal

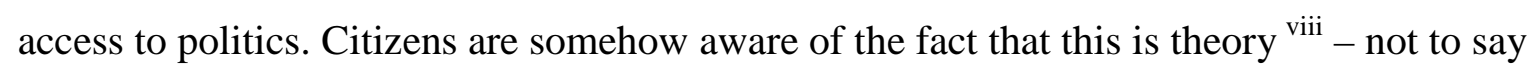


myth - and generally speaking, they defend themselves from it - notably by resisting even the idea of discussing politics (Conover and Searing, 2005) - whereas this is usually considered the very first step in political commitment ${ }^{\mathrm{ix}}$. How then can we design ways to observe and understand how lay citizens get involved in political discussion and engage with politicization if they don't want to?

Here, clearly, surveys hardly help as what we aim to analyze is the very process of translation of ordinary categories into political categories and vice and versa ${ }^{\mathrm{x}}$. The most obvious strategy is ethnography. Eliasoph, Hamidi and Cramer Walsh spent years observing people discussing political issues in civic groups involving either parents, neighbours and members of environmental or leisure associations (Eliasoph, 1998; Hamidi, 2010) or in informal groups (Cramer Walsh, 2004). Eliasoph and Hamidi show how people tend to avoid discussion of politics in public settings, even when they have concerns regarding political issues that they express in face-to-face conversations with the researcher. Cramer Walsh confirms that groups of acquainted people rarely address what happens in the political sphere, even if what matters to them might be considered by observers as political. All of these authors, then, actually end up studying de-politicization.

Gamson, on the contrary, choose to organize focus groups and confront lay citizens - and more specifically, working class people - with political issues (Gamson, 1992), in order to show that they have their own ways of discussing these and which are not reducible to media influence. His influential book shows that ethnography might not be the only - and possibly not the most efficient - way, to access and observe political discussion. In this case though, focus-groups convened pre-acquainted people in the hope of reproducing or generating naturalistic discussion among friends and relatives. One might want to go a step further and assume a more experimental approach. Indeed, focus groups, as a method for social scientists, have different origins: field and research action that value more contextualized ways of 
collecting data; also behavioral sciences that rely overtly on experimental methods (Morgan, 1997).

Moreover, feminists have largely supported the use of focus groups in social sciences. In a recent review article about focus group research, Kamberelis and Dimitriadis underline that the method, despite its apparent descent from media and marketing research, was widely used by research projects with explicitly political aims. A main argument here is that the group empowers interviewees and gives them the strength to resist the framework of interrogation and rephrase it in their own terms. Of course, using a method for politically-oriented action research or for political science research is not the same thing, but these authors also state: "In fact, focus groups are spaces where the personal can (and often does) become political.” (Kamberelis and Dimitriadis, 2014: 335).

Focus groups, if designed accordingly, allow discussions to evolve in unpredicted ways. They offer participants a space to take hold of the questions offered as stimulus and follow their own avenues as they help each other to express their mind. This makes them very useful to study politicization.

Generally speaking, at the individual level, we can distinguish between three kinds of information that might be collected or constructed within interviews, notably with lay citizens. First, factual data - let's call this information - regarding what happens or happened for them and their circumstances. Second, representations, that is, insights into the way interviewees see, understand or interpret what happens or happened to them or around them. Third, some sorts of competence that are involved in the way interviewees confront themselves with the discursive situation that the interview constitutes. These competences refer partly to (general) social and cognitive skills related to language and sociability. They also put at stake more specific abilities referring to the topic under discussion. Here, the relationship - be it distant or close - that interviewees entertain with politics is being tested, 
as it influences their ability to decipher other people’s political opinion or ideology, to make alliances and/or take a stand. It might also have consequences on their capacity to assume ambivalence and contradiction and, more importantly, to identify interests, including their own.

In-depth qualitative research on politicization allows for a focus mainly on this third kind of data: the competences lay citizens exert when they are confronted with a political topic. This can be done with face to face interviews but the relationship between a politically unsophisticated interviewee and an interviewer, who is, by construction, more knowledgeable in this matter, is unbalanced (Duchesne and Haegel, 2001). It does not leave much room for the former to "translate” the question into his/her own categories of experience. As a result, face-to-face interviews with lay citizens hardly confirm more than the distance between partners in this encounter and serve to underline citizens' negative feelings towards politics. It does not provide a window for understanding how they can engage with political issues - as everybody does at some point, even fleetingly. In focus groups, the relationships between participants might create the room that is needed to explore construction of meanings, provided that they have been designed in an appropriate way.

\section{How to design focus groups as test of politicization?}

As Morgan stated, the first lesson in order to avoid focus groups going wrong is to keep “looking at the project as a whole” (Morgan, 1995: 523) and thus make the decisions regarding design while keeping in mind what we are looking for. Following Morgan ${ }^{\mathrm{xi}}$, I shall address the ways focus groups should be designed in a study on politicization according to three headings: recruiting, sampling, developing questions and moderating. Analysis will be dealt with in the next section. 


\section{a. Recruiting purely lay citizens}

When health sociologists run focus groups, they recruit patients, GPs, nurses, or patients’ family members through relevant medical institutions or associations. When political sociologists try to study citizens or public opinion, they do not have access to such channels to reach them through providing a ready-made sampling pool. They could potentially interview anyone; but tend actually to interview people who are over-politicized. It is well-documented that the more remote people feel from the political field, the less likely they are to accept to participate in interviews, in general, and, in particular, in interviews on political topics (Gaxie, 1978). If we do want to understand the roots of de-politicization, it is of paramount importance to recruit lay citizens who reflect the diversity of the population both socially (not only in terms of social class but also ethnic, gender, generation wise) and politically. This is true for surveys and individual interviews; this is even truer for focus groups. Taking part in focus groups is more demanding, both because the meeting cannot be arranged at the time and place requested by the potential interviewee and because the idea of having to expose their own thoughts to others might be stressful. Researchers then tend to leave recruitment to public opinion research firms (for instance Baglioni and Hurrelmann, 2016; Stoker, Hay, and Barr, 2016; when they do not interview students as for exemple Bruter, 2005). These firms maintain panels and can provide - for a price - participants selected according to researchers’ criteria. But these panel members are not lay citizens with regard to their ability to discuss afresh any issue, including political ones: they are used to it, they have developed the skills for that. In this respect, they are not representative anymore of their fellow citizens, even when, on paper, they meet the sampling criteria.

It is, thus, particularly important for this kind of project to control the recruitment, as costly as it can be, in time and resources. The recruiting team has to make sure that the participants do not choose to participate because they are specifically interested in politics ${ }^{\mathrm{xii}}$; that is, no more 
so than an "average” citizen, which sets the bar quite low, in particular for less-educated people. In this case, in order to encourage participation, rewarding participants seems to be difficult to avoid. Moreover, special efforts have to be made in order to locate people in diverse and socially-contrasted environments: one has to access them where they live, where they work, where they go shopping, where they spend free time, instead of waiting for them to volunteer.

This can be all the more difficult if the team decides to recruit participants who don't know each other. Whether this is preferable to using pre-acquainted groups, however, is debatable. Observing how groups of relatives and/or friends react and discuss when they are confronted with political issues is just as interesting as observing a group of strangers doing the same - it is simply different and affords different insights. Gathering a group of acquainted people seems easier as you have "only" to convince one person to invite people s/he knows at his/her place, instead of convincing every single participant to come to an unknown location. On the other hand, when interviewing a group of relatives, you largely lose control of recruitment ${ }^{\mathrm{xiii}}$. Moreover, in this kind of design, participants tend to know about each other's general political opinions. It means that we don't get to see if and how people identify other people's positions; furthermore, it raises difficulties for understanding the grounds of their agreements and disagreements as they won’t necessarily make explicit what they’ve already shared ${ }^{\text {xiv }}$ (Leask, Hawe, and Chapman, 2001; Vicsek, 2007). It thus makes sense to go for unacquainted groups. It makes then the "test” more challenging as we know that people avoid discussing politics even more when they don’t already know the people with who they are speaking (Mutz, 2006)

When advertising for focus groups to investigate de-politicization, it is essential not to disclose the real purpose of the discussion. Firstly because advertising a discussion as political would reinforce the political selective process and prevent many people from volunteering; 
secondly because participants would tend to prepare. We had the occasion to confirm these expectations during our last project. The topic was on Europe and most participants to this series of groups, who were recruited to discuss "social issues”, made it clear that they actually thought it was not a social but a political issue. One of our Oxford groups had to stop after about an hour of discussion, due to unforeseen circumstances. It was meant to reconvene two weeks later. Although participants knew they would be rewarded again, had agreed to come back and had confirmed their participation, two participants out of five did not show up. A third one turned up but he had clearly prepared. This young Muslim man explicitly changed his mind between the two sessions, from expressing quite a positive and open attitude towards European integration to expressing a strong opinion against it, based on a firm position against secularization. In the second session, the discussion became almost impossible as this participant came along with the express purpose of stating his position, making it clear that he would not change his opinion, nor even listen to alternative views. This feature - advertising interviews without being clear about the topic and the aim of the research project - might be considered ethically problematic $^{\mathrm{xv}}$. In this case, it seems scientifically necessary. We thought it was acceptable: firstly, because what is political or not is however matter of discussion. Secondly, on no occasion, did we force or even solicit verbal contributions from individuals. In the case mentioned above, when three of the five original participants came back for a second try, one of them, the only woman, clearly struck by the harsh conflictive tone of the discussion, did not say a word and we let her remain silent. Lastly, we always kept some time at the end of the session for informal talk and some kind of debriefing. We tried to make sure all participants would go back home feeling comfortable $\mathrm{e}^{\mathrm{xvi}}$.

\section{b. Sampling: mixing social homogeneity and political heterogeneity}


Our project drew on a few decades of survey research in European studies. It had consistently been demonstrated that national and social belonging are the first two properties that influence individual attitudes towards European integration. But the reasons for that either remained largely to be explained (national) or were debated (social). We thus decided to sample our groups according to a double segmentation: national (France, UK and French-speaking Belgium) and social (working class, employees and executives). We also convened a fourth series of groups in each country with activists that we recruited via local branches of the main political parties in each country. They were meant to help with identifying the ideological arguments developed by parties, but, as we became aware of the "test of politicization”, we came to use it as a sort of control group: the comparison between the ways activists played the game and how others behave confirms the specific competences of the former and, by contrast, helps in identifying which competences lay non-activists citizens resort to in handling the discussion ${ }^{\text {xvii }}$.

Sampling by segmentation allows participants to find common ground in the discussion and spares some of them from being too heavily dominated by others; here, it seems all the more appropriate that politicization often involves disagreement and taking a stand. For the sake of the test, I would also recommend trying to mix social homogeneity with political heterogeneity. The recruitment involves asking questions of people who volunteer for the discussions, in order to ascertain their social characteristics. A few political questions may be introduced, in limited number, without disclosing what the discussion is about. For the same reason, it might be better to ask general value questions which are known as structuring political opinion - like attitudes towards the welfare state, immigration, authority, equality and order - rather than asking about electoral choices or positions on the left-right continuum. Adding political criteria into social sampling sometimes seems like squaring the circle when it comes to forming the groups, but it adds a lot to the efficiency of the test of politicization. 
c. Developing questions and moderating: adapting the nondirective approach to focus groups.

Focus groups, unless they are employed in order to interview more people in less time, are usually moderated in quite open ways. At least this is what is recommended by many experienced users. But the discussion is organized around the experience they share - be it a kind of illness and treatment, of violence or bad treatment, of practice or situation, etc. In political science, and in particular for our purpose, studying (de)politicization, the discussions are organized around topic(s) rather than common experience. That explains why we prefer to speak of the 'collective interview' (Duchesne and Haegel, 2009). The specific dynamic of focus groups, which relies on people adding up their narratives related to the same experience, does not work as such. We need other ways to fuel discussions in order to take full advantage of its potential, especially when the topic seems a little remote from personal experience; and preferably ways that would not put the moderator in the front stage. A possible source of inspiration is the nondirective interview.

The nondirective approach refers to a mix of Rogers’ proposal to translate counseling ways of listening to a patient into research interviewing, on the one hand, and methodological advices taken from the research program conducted in the 30's at the Western Electric company by Roethlisberger and Dickson, on the other hand. In France, this approach was supported by Michelat, a sociologist, trained as a psychologist, who worked in one of the leading political science research center (Michelat, 1975; Roethlisberger, Dickson, and Wright, 1975; Rogers, 1945). The main principle is to look for questions instead of answers: that is, to help interviewees formulate their own questions in relation to the topic under investigation. Here, for focus groups conceived as a test of politicization, it was, indeed, paramount not only to let participants behave in their own way, but also to induce them to express their doubts and 
questions. In a face-to-face non directive interview, the interviewer has to refrain him/herself from asking questions other than the introductory one and has to accommodate the interviewee by listening (and notably accepting silences needed for the interviewee to think), repeating, rephrasing what s/he says. We adapted the nondirective approach to collective interviewing with the following features:

Firstly, we opted for small groups. We invited six to seven participants, but were satisfied when four turned up. With such numbers, participants are in position to really talk to each other. It also gives everyone a chance to secure the floor without us having to ask them directly (unless we noticed that someone was trying in vain to have a say). In the larger groups (6 to 7 participants), there were always a couple of them who remained silent. Secondly, we employed a moderation technique used in consultancy in a way different from its original intention (which was solving problems in an organization). The technique consists of the moderator writing on cards what participants say as the discussion proceeds and pinning them up from time to time, using them to stimulate discussion when exchanges peter out. In doing so, the moderator gives back to the group the main points it is raising in a way that approximates what a nondirective interviewer does when s/he rephrases what the interviewee has already said in order to rekindle his/her discourse. Moreover, it provides the moderator with a task that induces him/her to stick to the participants’ words and also prevents him/her from intervening. Lastly, as participants are all positioned to face the board, it is easy to set up a video-recording. The camera reinforces the public character of the discussion, which was part of the test.

Thirdly, we asked a limited number of questions: five for three hours of discussion. The project was also dedicated, and funded as such, to the study of attitudes towards European integration. This topic remains - or remained, in 2006 - very unfamiliar for most people, thus we did not dare ask only one question, as we reckoned participants would have changed the 
topic quite quickly ${ }^{\text {xviii }}$. Indeed, this is what they did - French and British working class people and employees in particular. These five questions worked as reminder of what they were expected to discuss. It allowed us to avoid refocusing the discussion; a task that some participants actually assumed. However, we had plenty of time to keep the discussion going and let the participants take it where they wanted. We also took time for a break, with drinks and a snack, so that participants could talk informally and get to know each other a little bit. This set up - few participants, limited number of questions, no refocusing from the moderator, no prompting either, even to participants who remained largely silent and the writing up of the points or arguments on the board - gave a kind of nondirective tone to the moderation, made all the more evident in that we also facilitated the expression of disagreement. In a face-toface nondirective interview, as the interviewee explores the topic, his/her thoughts evolve and s/he comes to contradict most of the time or at least, to formulate some very ambivalent views. In a collective discussion, ambivalence and contradiction are also the rule - in particular, with regard to remote and imposing objects, such as political ones. But public contradiction among strangers is seldom considered normal social behavior. In this case, our original focus on conflictualization helped out. The series of questions was indeed elaborated, as said before, in order to facilitate conflict. Moreover, we used what was called "the flash rule" $^{\text {xix }}$ to make clear that expressing disagreement with something that had been said was perfectly acceptable and even appreciated. Participants made very different use of it, from asking for clarification to strongly disagreeing. Notably, they used it to challenge both the questions we asked them and conventional representations of the EU.

Altogether, our design did produce a kind of situation where participants successfully managed to discuss together a topic that they explicitly declared political - in particular, during the moment of informal talk; that is during the break and after the session. They managed it in different ways, both individually and collectively. 


\section{Analyzing : looking at alliances}

In the last decade, the literature on how to analyze focus groups and, in particular, how to take advantage of interaction among participants, has multiplied. Each author suggests his/her way to deal with this and report it. As Morgan notices, this is particularly the case for academic research users while more applied researchers are more "substantively" oriented (Morgan, 2010): the former pay more attention to the way things are said and the latter to what is said. Using focus groups to set up a test of politicization clearly points in the first direction. Politicization, understood as a process of adaptation to a special field - the one of government and power -, is performed with varied types of behavior, skills and knowledge. Those are what we aim to analyze. This does not mean that the topic itself - here Europe - is not part of the test for politicization; nor that the topic itself does not interest us as researchers ${ }^{\mathrm{xx}}$. Discussion is facilitated by topics that are closer to daily experience and for which partisan repertoires are clearer and more readily available to lay citizens; moreover how things were said constitute the core of the analysis of the process of politicization.

Following Hay, I do not consider that political discourse analysis should be viewed as a specific kind of analysis (Hay, 2013). Politics is about power, from agency to domination. Moreover, here we are looking for translation and adaptation from social fields to the political. When it comes to lay people, power refers frequently to collective actors and empowerment to belonging. In addition, political opinions are by nature controversial: they refer to alternative ways to distribute wealth among people - politics being "who gets what, when and how” (Lasswell, 1950) - and/or to partisan or politicians’ manifestos in competition.

Here again, focus groups are very appropriate for observing and understanding how people interact together in order to deal with the incitement to talk politics. Basically, they have to 
make alliances in the group in order to formulate views or take a stand in front of the others or altogether, as a group, in opposition to an external other. In our specific case, as participants were chosen because they had, at least on paper, opposing political views, we could expect the discussions to get polarized; but this does not always happen: the groups also tend to look for and develop a common ground against a more or less defined other, which is sometimes embodied in the research team.

The way to analyze the discussions does not differ from reports from other focus groups users interested in interactions (Belzile and Öberg, 2012; Duggleby, 2005; Lehoux, Poland, and Daudelin, 2006; Stevens, 1996). We developed our own way drawing on Billig and Kitzinger and Farquhar (Billig, 1992; Billig, 1991; Kitzinger and Farquhar, 1999). We produced an interpretative narrative account for each discussion, based on video recording, field notes and questionnaires, looking at what happened between participants (Our template is detailed in Duchesne et al., 2013:190-192). We interpreted what was said as chain reactions depending from what the speaker had heard and understood (or might have) from what had been said before, rather than an expression of his/her pre-existing opinions. These accounts were discussed by the research team. In a way, they constitute the data as much as do the transcripts themselves. Our first results are indeed a comparison of these narratives (Duchesne et al., 2000), according to our double segmentation, national and social. Content analysis came second, along with more specific discourse analyses. Here, the video recording was a decisive element. We could never have produced these interpretative accounts without looking at the ways participants behaved, who they were looking at and paying attention to, and how. Body language was an intrinsic part of the play. When looking at the recordings, it is impossible to deny that discourse is action (Potter and Wetherell, 1994).

The comparison between the narratives shows that participants performed the test of politicization in very different ways. In a nutshell, regarding the location, Belgian groups are 
more sophisticated and deliberative, the French more conflictual and the British quite obsessed with knowledge. Regarding social belonging, we see how executives rely on personal/individual resources, while working class groups struggle to find common ground despite their differences - in particular, ethnic ones. Attachment to the Welfare State seems to constitute one of the most powerful sources for this. Following Hydén and Bülow who suggest looking for who is talking in the groups (Hydén and Bülow, 2003), we notice also that these groups - executive compared with working class ones - do not address their fellow participants by putting forward the same aspects of their identity. Executives mainly speak as professionals and cultural-nationals (or cosmopolitans) while working class participants refer to their experience as governed people.

There is one dimension that we did not take into account when recruiting participants - as the “test of politicization” was not foreseen - and which happens to be very important: the participants’ degree of political interest. In groups where one (or more) of them happens to be an activist, s/he strongly influences the discussion, leading others to adapt to the situation. The comparison with activist groups here is very heuristic and reinforces the experimental aspect of our design. They clearly feel comfortable with the topic and the situation and play their parts according to their political affiliation. They easily identify others participant's political belonging and challenge them accordingly. They make fun of conflict and competition. They don't need allies in the group to take a stand: their party provides them with permanent allies and allows them to speak for a collective even when they are isolated in the focus group. These features, characteristic of the activists groups, can then be observed in the other groups where they are only residual and could not easily be identified without knowing the whole picture.

\section{Conclusion}


In this chapter, I tried to draw lessons from a focus group study, originally designed to analyze attitudes towards European integration and conflictualization, but which turned out to function for participants as a "test of politicization". In the current and growing context of disaffection towards politics, what can we learn from it in this respect?

Firstly, our study confirms what is already well documented about people’s distrust towards politicians and disaffection regarding politics. In these discussions, participants rarely mention parties and political actors, and, when they do, they associate them either with the media and show-business, or with corruption and selfishness.

Secondly, it demonstrates that disaffection is not a question of incompetence or carelessness. While they might sometimes be mistaken, participants report lots of information about the state of the world. They clearly seek to keep themselves informed. The ways in which they understand what is going on with globalization certainly cannot be viewed as being stupid. In this respect, it helps in explaining the puzzling relationship between the population's growing educational level and their growing disaffection for politics.

More importantly, these data provide an unparalleled resource for studying collective belongings or identifications and their transformation. As Tilly said, identities "play an indispensable role in the sealing of agreements and the coordination of social interaction” (Tilly, 2003: 608). As a consequence, they are indispensable for political agency. In these groups, when interacting with each other in order to find a common way to talk politics, participants disclosed much of the parts of their identities that can generate a common ground. Among these, being governed, being subjected to the same rules and the same policies, appears to be particularly important - at least for working class groups; more important, indeed, than being fellow citizens (understood here as being "the sovereign people”, the voters). 
The richness of this data is the consequence of a series of decisions we made when we designed the discussions, and then tried to apply in a systematic way. Recruitment was a big deal. We choose to select our participants one by one and arranged our groups carefully in order to maximize social homogeneity and political heterogeneity. We assumed the experimental dimension of our design in a scientific context that tends to prefer observation in real life. We adapted a moderation technique used by consultancy in order to create the conditions for collective non-directive interviewing. We asked a limited number of questions and made sure participants would have the time to get used to the situation and find their ways to deal with it. Before any kind of content analysis, we went through an interpretative stage where we paid full attention to the way the relationship between the participants - and us evolved. Lastly, we took our time before reaching to conclusions. Indeed, we are still analyzing this data. We ran these groups in 2006, two books have already been published using this data and yet we continue working on it. Focus groups might sometimes be used in applied research for quick answers; but they do provide researchers with very rich qualitative data for which there is, apparently, "never the last word” (Andrews, 2008).

\section{Acknowledgements}

I'm very much indebted to Florence Haegel, with whom I worked for many years and with whom I experimented with regard to this focus group design; as well as Elizabeth Frazer and Virginie Van Ingelgom, co-authors of the book Citizens reactions to European integration compared: Overlooking Europe. I'm also grateful to Claire Dupuy, with whom I continue to revisit this data. Special thanks to Virginie who commented on the first version of this chapter, as well as this’ volume editors, and more particularly Rose Barbour who turned it into readable English. 


\section{Bibliography}

Andrews, Molly (2008) 'Never the Last Word: Revisiting Data’, in M.Andrews, C.Squire and

M.Tamboukou (eds.), Doing Narrative Research. London: SAGE Publications. pp. 87-101.

Baglioni, Sebastian, and Hurrelmann, Achim (2016) 'The Eurozone Crisis and Citizen

Engagement in EU Affairs’, West European Politics, 39(1): 104-124.

Barbour, Rosaline (2007) Doing Focus Groups. London: SAGE.

Belzile, Jacqueline A. and Öberg, Gunilla (2012) 'Where to Begin? Grappling with How to Use Participant Interaction in Focus Group Design', Qualitative Research, 12(4): 459-472.

Billig, Michael (1991) Ideology and Opinions: Studies in Rhetorical Psychology. London: SAGE.

Billig, Michael (1992) Talking of the Royal Family. London: Routledge.

Bourdieu, Pierre (1977) ‘Questions de Politique’, Actes de La Recherche En Sciences Sociales, 16(1): 55-89.

Bourdieu, Pierre (1993) ‘Comprendre’, in P.Bourdieu (ed.), La Misère Du Monde. Paris : Le Seuil. pp. 903-925.

Bruter, Michael (2005) Citizens of Europe? The Emergence of a Mass European Identity. New York: Palgrave Macmillan.

Conover, Pamela J. and Searing, Donald D (2005) 'Studying “Everyday Political Talk” in the Deliberative System', Acta Politica, 40(3): 269-283.

Cramer Walsh, Katherine (2004) Talking about Politics: Informal Groups and Social Identity in American Life. Chicago: The University of Chicago Press.

Dahl, Robert A. (1989) Who Governs? Democracy and Power in an American City. New Haven: Yale Univ. Press.

Dahl, Robert A. (2006) A Preface to Democratic Theory. Expanded ed. Chicago: University of Chicago Press. 
Déloye, Yves (2007) ‘Pour une sociologie historique de la compétence à opiner « politiquement »: Quelques hypothèses de travail à partir de l’histoire électorale française', Revue française de science politique, 57(6): 775-798.

Dervin, Fred (2015) Analyser l'identité: les apports des focus groups. Paris: L’Harmattan. Duchesne, Sophie, Frazer, Elizabeth, Haegel, Florence and Van Ingelgom, Virginie (2013) Citizens’ Reactions to European Integration Compared: Overlooking Europe. Houndmills: Palgrave Macmillan.

Duchesne, Sophie, Haegel, Florence, Frazer, Elizabeth et al. (2000) 'Europe between Integration and Globalization. Social Differences and National Frames in the Analysis of Focus Groups Conducted in France, Francophone Belgium and the UK’, Politique Européenne, (30): 67-106.

Duchesne, Sophie, and Haegel, Florence (2001) 'Entretiens Dans La Cité. Ou Comment la parole se politise’, EspacesTempsLesCahiers, (76-77): 95-109.

Duchesne, Sophie, and Haegel, Florence (2004) 'La Politisation des discussions, au croisement des logiques de spécialisation et de conflictualisation', Revue Française de Science Politique, 54(6): 877-909.

Duchesne, Sophie, and Haegel, Florence (2009) L'enquête et ses méthodes: l'entretien collectif. Paris: A. Colin.

Duchesne, Sophie, and Haegel, Florence (2010) ‘What Political Discussion Means and How Do the French and (French Speaking) Belgians Deal with It' in Wolf M. R., Morales, L. and Ikeda K. (eds), Political Discussion in Modern Democracies in a Comparative Perspective. London: Routledge. pp. 44-61

Duggleby, Wendy (2005) 'What About Focus Group Interaction Data?’, Qualitative Health Research, 15(6): 832-840. 
Eliasoph, Nina (1998) Avoiding Politics: How Americans Produce Apathy in Everyday Life.

Cambridge: Cambridge University Press.

Gamson, William A. (1992) Talking Politics. Cambridge: Cambridge University Press.

Garcia, Guillaume, and Haegel, Florence (eds.) (2011) 'Entretiens collectifs: nouveaux usages?' Revue française de science politique, 61(3).

Gaxie, Daniel (1978) Le Cens Caché: Inégalités Culturelles et Ségrégation Politique. Paris:

Le Seuil.

Gaxie, Daniel, Hubé, Nicolas and Rowell, Jay (eds.) (2011) Perceptions of Europe: A

Comparative Sociology of European Attitudes. Colchester: ECPR Press.

Guillemette, François, Luckerhoff, Jason and Baribeau, Colette (2010a) ‘Entretiens de

Groupe : Concepts, Usages et Ancrages vol.1', Recherches Qualitatives, 29(1).

Guillemette, François, Luckerhoff, Jason and Baribeau, Colette (2010b) 'Entretiens de

Groupe : Concepts, Usages et Ancrages vol.2’, Recherches Qualitatives, 29(3).

Hamidi, Camille (2010) La Société civile dans les cités: engagement associatif et politisation dans des associations de quartier. Paris: Economica.

Hay, Colin (2009) 'Disenchanted with Democracy, Pissed off with Politics’, British Politics, 4(1): 92-99.

Hay, Colin (2013) 'Political Discourse Analysis: The Dangers of Methodological Absolutism', Political Studies Review, 11(3): 321-327.

Hydén, Lars-Christer, and Bülow, Pia H. (2003) ‘Who’s Talking: Drawing Conclusions from Focus Groups—some Methodological Considerations’, International Journal of Social Research Methodology, 6(4): 305-321.

Kamberelis, George, and Dimitriadis, Greg (2014) 'Focus Group Research: Retrospect and Prospect' in Patricia Leavy (ed.),The Oxford Handbook of Qualitative Research. Oxford: Oxford University Press. Ch.16. 
Kitzinger, Jenny, and Farquhar, Clare (1999) 'The Analytical Potential of "sensitive Moments” in Focus Group Discussions’, In Rose Barbour and Jenny Kitzinger (eds.), Developing Focus Group Research. London: SAGE. pp. 156-172.

Lagroye, Jacques (ed.) (2003) La Politisation. Paris: Belin.

Lasswell, Harold Dwight (1950) Politics: Who Gets What, When, How. New York: P. Smith. Leask, Julie, Hawe, Penelope and Chapman, Simon (2001) Focus Group Composition: A Comparison between Natural and Constructed Groups, Australian and New Zealand Journal of Public Health, 25(2): 152-154.

Lehoux, Pascale, Poland, Blake and Daudelin, Genevieve (2006) 'Focus Group Research and “the Patient’s View.”, Social Science \& Medicine, 63(8): 2091-2104.

Michelat, Guy (1975) 'Sur l’utilisation de l'entretien non directif en sociologie’, Revue Française de Sociologie: 229-247.

Morgan, David L. (1995) ‘Why Things (Sometimes) Go Wrong in Focus Groups’, Qualitative Health Research, 5(4): 516-523.

Morgan, David L. (2010) 'Reconsidering the Role of Interaction in Analyzing and Reporting Focus Groups’, Qualitative Health Research, 20(5): 718-722.

Morgan, David L. (1996) Focus Groups as Qualitative Research. Thousand Oaks, Calif: Sage Publications.

Mutz, Diana Carole (2006) Hearing the Other Side: Deliberative versus Participatory Democracy. Cambridge: Cambridge University Press.

Potter, Jonathan, and Wetherell, Margaret (1994) ‘Analyzing Discourse’ In Alan Bryman and Robert Burgess (eds.) Analyzing Qualitative Data. London and New York: Routledge. pp. 47-66. 
Roethlisberger, Fritz J. and Dickson, William J. (1975) Management and the Worker: An Account of a Research Program Conducted by the Western Electric Company, Hawthorne Works, Chicago. Cambridge, Mass.: Harvard Univ. Press. (1 ${ }^{\text {st }}$ edition 1939)

Rogers, Carl R. (1945) 'The Nondirective Method as a Technique for Social Research’, American Journal of Sociology, 50(4): 279-283.

Sniderman, Paul M., and Grob, Douglas B. (1996) 'Innovations in Experimental Design in Attitude Surveys', Annual Review of Sociology, 22: 377-399.

Stevens, Patricia E. (1996) 'Focus Groups’, Public Health Nursing, 13(3): 170-176.

Stoker, Gerry (2009) 'What’s Wrong with Our Political Culture and What, If Anything, Can We Do to Improve It? Reflections on Colin Hay’s "Why We Hate Politics”, British Politics, 4(1): 83-91.

Stoker, Gerry, Hay, Colin and Barr, Matthew (2016) 'Fast Thinking: Implications for Democratic Politics’, European Journal of Political Research, 55(1): 3-21.

Tilly, Charles (2003) 'Political Identities in Changing Polities’, Social Research, 70(2): 605620.

Van Ingelgom, Virginie (2014) Integrating Indifference. A Comparative, Qualitative and Quantitative Approach to the Legitimacy of European Integration. Colchester: ECPR Press. Vicsek, Lilla (2007) ‘A Scheme for Analyzing the Results of Focus Groups’, International Journal of Qualitative Methods, 6(4): 20-34.

White, Jonathan (2010) 'European Integration by Daylight', Comparative European Politics, 8(1): 55-73.

de Wilde, Pieter, Leupold, Anna and Schmidtke, Henning (2016) 'Introduction: The Differentiated Politicisation of European Governance', West European Politics, 39(1): 3-22. Zürn, Michael (2016) ‘Opening up Europe: Next Steps in Politicisation Research’, West European Politics, 39(1): 164-182. 
${ }^{\mathrm{i}}$ This chapter draws on work that I did a couple of years ago with Florence Haegel. See the many references to our common publications in the text.

ii There were three main differences between the experimental study and this one, on top of the comparison and the number of groups: the topic then - Europe instead of delinquency; the location the French groups were convened in rooms where Sciences Po, a French elite school for higher education, was highly visible which was not the case for the preliminary study; and the recruitment: the first time, we recruited them though a job centre while the second time, we advertised widely and looked for them directly.

iii The groups were convened in 2006. A couple of qualitative studies at the time showed how remote the EU was for people. P.Lehingue even suggested that producing opinions on European questions requires a specific competence, a squared one. (Gaxie, Hubé, and Rowell, 2011: ch.8)

iv In reference to Haskier's chapter in this book, what happened in these groups is probably not recognisable to participants' everyday contexts. On the contrary, the situational context of these focus groups is meant to activate the processes that prevent politicization to happen in everyday contexts.

${ }^{\vee}$ What is referred to in French as objective and subjective competence, the first (equivalent to political sophistication) being mostly knowledge and understanding of political actors, institutions, rules, issues, etc. and the second, confidence in her/his own authority and capacity to have a say (Bourdieu, 1977; Gaxie, 1978)

vi In reference to William Gamson's book who contributed to (re)introduce focus groups in sociology and political science (Gamson, 1992).

vii The advantages of passive citizenship, that might also be considered a sign of satisfaction on the part of citizens, have long been debated. Representation makes democracy work with limited citizens' involvement. See for instance earlier work of Dahl (Dahl, 2006; Dahl, 1989)

viii As confirmed by the discrepancy between the recurrent support for democracy expressed in survey and the not less recurrent and even growing disgust for politics (Hay, 2009)

${ }^{i x}$ I writing these lines when France experiences a version of the Occupy movement, the Nuits debouts, which illustrates dramatically how political engagement begins with learning (and here possibly reinventing) political discussion. http://www.theguardian.com/world/2016/apr/08/nuit-deboutprotesters-occupy-french-cities-in-a-revolutionary-call-for-change

${ }^{x}$ Although some experimental survey design could help (Sniderman and Grob, 1996) 
${ }^{x i}$ The points I shall make in this section indeed follows most of Morgan suggestions made in this 1995 article. This is no wonder as we made intensive use of this paper when we designed our focus groups. ${ }^{x i i}$ Nor because they take a special interest in social science, as this would not make then representative either of the "average" citizens.

xiii That was Gamson's strategy and he notes that interviewees tend to invite those who they reckon would be most competent and who happened to be the most educated and/or belong to the highest social groups in their acquaintance.

${ }^{\mathrm{xiv}}$ A similar experience than interviewing people you know (Bourdieu, 1993)

${ }^{x v}$ Let's note that ethical issue are generally speaking less considered in France that in the UK or the US, which might explain that we decided to go that way. It seems however to be the right decision for our purpose.

xvi In the Oxford case, we had to get participants to read and fill forms that acknowledge that the discussion could become harsh and where they confirm they would ask for help if they feel disturbed by it. This was neither required in Paris nor in Brussels.

xvii We followed Morgan's advice and run two groups of each. This turned out particularly useful for the comparison. Because of the many accidents that characterize recruitment - notably people who happen to be really different from what they look on paper on the one hand and those who don't show up on the day of the event on the other hand -, we ended up with working class, employees and executive of different sorts. Once we had completed the series, we organized our groups in two sets: in the first one, we put the twelve groups that distributed the more evenly in the three countries along the social spectrum (Garcia and Van Ingelgom, 2010) - and the political spectrum for militants. National comparison relies on this first series only.

xviii We did some tests groups in the three countries beforehand that confirmed than more than one question was needed and helped phrasing them.

${ }^{x i x}$ Participants were told from the beginning that if they did not agree with what someone was saying, instead of interrupting, they could let the moderator know. She would then draw a 'flash' on the card and come back to it later. The first time a participant asked for a flash, the moderator thanked her/her, indicated that she was in pleased. This indeed helped making disagreement known.

${ }^{x x}$ Indeed, most of the publications that resulted from our focus groups analysis address the topic itself (Duchesne et al., 2000; Duchesne et al., 2013; Van Ingelgom, 2014) 